\title{
Analysis of Economic and Social Costs of Growing Petunia $\times$ hybrida in a Greenhouse Production System Using Alternative Containers
}

\author{
Robin G. Brumfield ${ }^{\mathbf{1}}$ and Laura B. Kenny \\ Department of Agricultural, Food, and Resource Economics, Rutgers, The State University of New Jersey, 55 Dudley \\ Road, New Brunswick, NJ 08901
}

Alyssa J. DeVincentis

Department of Land, Air, and Water Resources, University of California, Davis, 1 Shields Avenue, Davis, CA 95616

Andrew K. Koeser

Department of Environmental Horticulture, Center For Landscape Conservation and Ecology, IFAS, University of Florida-Gulf Coast Research and Education Center, 14625 County Road 672, Wimauma, FL 33598

\section{Sven Verlinden}

West Virginia University, Davis College of Agriculture, Natural Resources \& Design, 4100 Agricultural Sciences Building, P.O. Box 6108, Morgantown, WV 26506-6108

\author{
A.J. Both \\ Department of Environmental Sciences, Rutgers, The State University of New Jersey, 14 College Farm Road, New \\ Brunswick, NJ 08901 \\ Guihong Bi \\ Department of Plant and Soil Sciences, Mississippi State University, Mississippi State, MS 39762
}

Sarah T. Lovell

Department of Crop Sciences, University of Illinois at Urbana-Champaign, 1009 Plant Sciences Laboratory, 1201 S. Dorner Drive, Urbana, IL 61801

\section{J. Ryan Stewart \\ Department of Plant and Wildlife Sciences, Brigham Young University, 4105 Life Sciences Building, Provo, UT 84602}

Additional index words. biocontainers, sustainable, cost analysis, carbon footprint, social cost, global warming potential

\begin{abstract}
Greenhouse growers find themselves under increasing pressure to respond to consumer preferences to use environmentally sustainable practices and materials while maintaining profitable operations. These consumer preferences reflect a mounting awareness of the environmental issues, such as climate change and their associated social costs. Ideally, sustainable horticultural production accounts for both traditional economic considerations and such social costs, some of which can be explained through the calculation of global warming potential (GWP). An obvious candidate for a sustainable intervention is the traditional plastic pot, which growers can replace with alternative biocontainers with varying degrees of GWP. This study calculates the variability of direct costs of production using alternative containers to offer a comparison of social and economic costs. We evaluated these direct costs of producing petunia (Petunia $\times$ hybrida) grown in pots made of traditional plastic, bioplastic, coir, manure, peat, bioplastic sleeve, slotted rice hull, solid rice hull, straw, wood fiber, and recycled reground plastic containers used in a previous assessment of GWP. Our analysis of the costs when using a traditional plastic pot showed that the highest contributors to GWP were different from the highest contributors to direct costs, revealing that the price does not reflect the environmental impact of several inputs. Electricity, the plastic shuttle tray, and the plastic pot contributed most to GWP, whereas labor, the plastic container, and paclobutrozol growth regulator contributed most to direct cost of production (COP). At $64 \%$ of total cost, labor was the most expensive input. Watering by hand added another \$0.37-\$0.54 per plant in labor. When we analyzed input costs of each alternative container separately, container type had the largest impact on total direct costs. Before adding container costs, the direct COP ranged from $\$ 0.56$ to $\$ 0.61$ per plant. After adding containers, costs ranged from $\$ 0.61$ to $\$ 0.97$ per plant. Wood fiber pots were the most expensive and recycled reground plastic pots were the least expensive in this study. Based on our assessment and the observed small variation in GWP between alternative containers, growers would benefit from selecting a container based on price and consumer demand. Some social costs that we are not aware of yet may be associated with some or all biocontainers.
\end{abstract}

As a high-input industry, greenhouse production relies on many nonrenewable and petroleum-based products. Pesticides, fertilizers, heating, irrigation, and plastic packaging rank among such inputs, which are associated with undesirable environmental impacts (Evans and Hensley, 2004). The long-term sustainability of the horticulture industry may be an area of concern for "green" customers who take the social cost of carbon into account when making purchasing decisions. The social cost of carbon is an indirect measure of damage from additional $\mathrm{CO}_{2}$ emissions and is an approximation of how climate change affects economic welfare (Moore et al., 2017; Nordhaus,
2017). Companies with environmentally conscious practices can increase profitability by targeting customers who consider environmental impacts (Russo and Fouts, 1997). Sustainable practices that use renewable and biodegradable inputs in floricultural production systems constitute an area of growing interest to consumers and producers alike, yet 
the economic components have not been fully explored to date (Behe et al., 2013; Dennis et al., 2010). Although consumers are willing to pay more for products that are favorable to the environment, growers often fear that sustainable production practices will not be compatible with their existing production systems (Dennis et al., 2010; Laroche et al., 2001). This study explores the economic feasibility and social cost impact of incorporating alternative containers into a greenhouse production system by using petunia as a model crop.

Alternative containers have reduced environmental impacts compared with their traditional plastic counterparts (Schrader et al., 2016). Plastic containers lead to disposal issues, and recycling facilities are often unwilling to accept plastic containers if they have soil or media residue (Hall et al., 2010). Alternative containers can potentially decrease plastic landfill wastes and reduce the petroleum-based inputs in greenhouse production by replacing traditional plastic pots, which account for $16 \%$ of the carbon footprint of a finished petunia plant (Koeser et al., 2014).

Despite these potential benefits, adoption of alternative containers will only become a reality if growers do not perceive their use as an economic risk. The impact of alternative containers on yield can be unpredictable because the effect of container type on plant growth has been variable, can depend on location and species, and often leads to higher water use (Evans and Hensley, 2004; Koeser et al., 2013; Sun et al., 2014). Our study looks at the economic cost of producing a flat of petunia plants grown in containers made from alternative materials, including bioplastic, coir, manure, peat, bioplastic sleeve, slotted rice, solid rice, straw, wood fiber, and recycled, reground plastic.

Biodegradable, compostable, or bioresin containers are "green" products that have become increasingly popular over the past several years (Lubick, 2007). Hall et al. (2009) reported that most of the growers viewed sustainable practices as "very important," and found recycling plastic pots to be the most common sustainable practice in place. The surveyed growers valued sustainability in their operations, but positive attitudes were not enough to predict their behavior, given that they were concerned about the ease of implementation and pro-

\footnotetext{
Received for publication 5 Mar. 2018. Accepted for publication 18 June 2018.

This research was partially funded by the USDA Specialty Crops Research Initiative Grant number 2010-01190 with matching resources from Rutgers, the State University of New Jersey. This project was supported by the USDA National Institute of Food and Agriculture, Hatch project numbers NJ02278, KY011032, MICL02010, TEX09045, TEN00406, and MIS211090. The authors appreciate assistance from Griffin Greenhouse Supplies, Summit Plastic Company, and BFG Supply Co.

${ }^{1}$ Corresponding author. E-mail: brumfiel@njaes. rutgers.edu.
}

duction risks of implementing sustainable practices. Consumers are also concerned with sustainability and value container types over any other input when making a purchasing decision (Hall et al., 2010).

Previous research by Koeser et al. (2014) examined the cradle-to-gate impacts of alternative container use in greenhouse production of a petunia plant. They performed a GWP assessment (U.S. EPA, 2012) to help commercial growers identify secondary impacts associated with their sustainable practices. The GWP is a metric that assesses how much additional heat is trapped in the atmosphere by the release of greenhouses gasses (e.g., carbon dioxide, methane, and nitrous oxide) for the inputs and activities within the predefined boundaries of the study. The cradle-to-gate life cycle analysis performed by Koeser et al. (2014) began with propagation from seed at a large, semimechanized wholesale greenhouse in Illinois that supplies retailers throughout the Midwestern United States. Seed production and transport were not included. After germination, they grew seedlings in a greenhouse until they were large enough to transplant from their initial plug tray cell to a larger, final container and into a shuttle tray for subsequent outdoor production. Once plants were market-ready, Koeser et al. (2014) transported them to the largest urban garden retail center in the distribution range for sale in Chicago (322 $\mathrm{km}$ round trip is the distance from the grower to the largest urban center in its distribution range. Total transportation costs included $1,172 \mathrm{~km}$ in total, i.e., $110 \mathrm{~km}$ for pesticides, fertilizers, and commercially produced plug growing mix; $148 \mathrm{~km}$ for perlite; $740 \mathrm{~km}$ for plastic containers and trays; and $348 \mathrm{~km}$ round trip to final destination). The life cycle analysis that they performed did not consider emissions associated with the production of capital goods (e.g., the greenhouse facilities and mechanized equipment) used to produce the plants. As reported by Koeser et al. (2014), most of the carbon emissions (expressed in $\mathrm{kg}-\mathrm{CO}_{2}$ equivalents) came from the electrical consumption used for supplemental lighting, whereas wood heating resulted in a minimal contribution to carbon emissions. Other notable inputs contributing to the total GWP included the plastic tray $(20 \%)$, plastic container $(16 \%)$, and peat $(7.7 \%)$. Our research used those results to provide a comparison of economic and social costs related to using alternative containers in greenhouse production systems. These emission values are one indicator of the social costs of production inputs associated with negative impacts on our environment.

Sustainable horticultural production ideally accounts for both traditional economic considerations and the social costs associated with negative environmental impacts, such as greenhouse gas emissions. Our objective was to explore the economic and social costs of integrating alternative containers into greenhouse production of a petunia plant, which is one of the most widely produced ornamental crops in the world (Vandenbussche et al., 2016). The results of this study can be widely applied to other annual crops. We used a cradle-to-gate carbon footprint assessment from previous research (Koeser et al., 2014), which we supplemented and enhanced with additional data, to estimate a more complete COP budget for a flat of petunia plants grown in plastic pots and alternative pots. We subsequently compared these budgets. The results of this study will help commercial growers determine the economic and social costs potentially associated with adopting alternative containers into their production systems.

\section{Materials and Methods}

We estimated direct costs based on data collected by Koeser et al. (2014), who tracked material and energy inputs required to produce a petunia plant from initial propagation to plant-and-container delivery to a retail center. Petunia, as an ornamental crop, serves as a suitable model system and provides representation for other widely produced annual horticultural crops. Wholesale value of petunias in 2015 totaled \$56,509,000 (USDA National Agricultural Statistics Service, 2016). Koeser et al. (2014) determined the GWP of each input based on interviews, published literature, proprietary data sources, direct measurements at a greenhouse facility, and university experiments. The present study looked at the secondary impacts associated with each container type used. We calculated the direct cost of the 10 inputs, each of which contributed more than $0.5 \%$ to the overall GWP of a single finished plant in a $10-\mathrm{cm}$ diameter, $480-\mathrm{cm}^{3}$ volume, traditional plastic container to compare GWP and input price (Table 1). Inputs varied by container type, allowing us to differentiate the direct cost of using each alternative container separately.

As indicated, we calculated costs of some additional inputs not included in the Koeser et al. (2014) study for a more complete estimate of the COP. We determined the cost of electricity and heating based on the $\mathrm{kWh}$ determined by Koeser et al. (2014) and the electric power monthly report (U.S. Energy Information Administration, 2017). We determined the costs of growing mix (Fafard 2 horticultural peat and expanded perlite; Conrad Fafard Inc., Agawam, MA), fertilizer solution $(14 \mathrm{~N}-2 \mathrm{P}-20 \mathrm{~K}$ mixed at $100 \mathrm{ppm}$ $\mathrm{N}$, applied in irrigation water), and plastic trays based on prices obtained from greenhouse suppliers (Summit Plastic Company, Akron, $\mathrm{OH}$, and Griffin Greenhouse Supplies, Inc., Tewksbury, MA). We documented the weight of the growing mix in each alternative container and the amount of fertilizer applied during the 2014 study. We determined transportation costs based on a quote from a greenhouse supplier (Griffin Greenhouse Supplies, Inc.) and data from Hall and Ingram (2014).

Several greenhouse distributors provided prices for the alternative containers 
(Griffin Greenhouse Supplies, Inc.; CowPots Manufacturing and Sales, East Canaan, CT; Summit Plastic Company; BFG Supply, Burton, OH; Johnny's Selected Seeds, Fairfield, $\mathrm{ME})$. Although the bioplastic pot and bioplastic sleeve are no longer commercially available, we included prices from when they were sold. We could not determine the price point for the straw pot, but we still calculated the variable costs associated with it for comparison. In addition to the 10 containers analyzed by Koeser et al. (2014), we analyzed the costs of a reground and recycled plastic pot, which is one of the cheapest alternative containers currently available in the market, but the previous study did not evaluate its GWP. For comparison, we used the inputs of a plastic pot (amount of growing mix, fertilizer, etc.).

The GWP assessment by Koeser et al. (2014) did not include several components normally included in a direct-cost calculation because their $\mathrm{CO}_{2}$ emissions did not meet the stated threshold. To calculate realistic direct costs for our analysis, we also included seed, growth regulators, pesticides, labor, municipal water, and any other input contributing \$0.001 per plant or more in the calculation. Although municipal water accounted for only $27.2 \%$ of irrigation based on a national greenhouse survey in 2008 (Hodges et al., 2015), it is an uncommon irrigation source for greenhouses. Nevertheless, we included it to be thorough, using 2017 municipal water prices from Chicago (Circle of Blue, n.d.).

Ball Seed (Chicago, IL) supplied petunia seed at a cost of $\$ 0.0079$ per seed. The Koeser et al. (2014) study followed common greenhouse practices for petunia, applying two fungicides [pyroclostrobin + boscalid (Pageant; BASF, Florham Park, NJ) and etridiazole + thiophanate-methyl (Banrot; Scotts-Sierra Crop Protection Company, Marysville, $\mathrm{OH})$ ], two growth regulators [ethephon (Florel; Lawn and Garden Products, Inc., Fresno, $\mathrm{CA}$ ) and paclobutrazol (Piccolo; Fine Agrochemicals, Ltd., Walnut Creek, CA)], and two insecticides [Paecilomyces fumosoroseus strain FE 9901 (NoFly; Natural Industries, Inc., Spring, TX) and imidacloprid (Mallet; Nufarm Americas, Inc., Burr Ridge, IL)] throughout the growth of the crop. We documented the amount of each chemical used. Etridiazole + thiophanate-methyl fungicide and paclobutrozol growth regulator applications varied by biocontainer type because of differences in soil volumes (A.K. Koeser, unpublished data).

A grower who was involved with the Koeser et al. (2014) study provided labor estimates (M. Flack, personal communication). We estimated labor costs using the methods described in Brumfield et al. (2015). Although the Koeser et al. (2014) study used overhead irrigation, hand watering is also a common practice and increases labor needs. Consequently, we calculated the cost of labor for hand watering to determine if this practice significantly affects COP. Koeser et al. (2013) recorded the total amount of time it took to hand water impatiens (Impatiens capensis) and lavender (Lavandula angustifolia) plants over their entire growth period for two years in the same alternative containers analyzed in this study. They found significant differences in watering times between the container types for lavender. Although impatiens and lavender have different growth characteristics, the authors averaged the amount of time spent on watering on a weekly basis for each crop and then averaged them together. They applied these values to the 9-week growth period of petunias to calculate the labor cost of hand watering by container type.

Based on grower input, Koeser et al. (2014) estimated a $10 \%$ cull rate during the plug production stage and a $2 \%$ cull rate during the final production stage. As such, we adjusted all costs for the present study to reflect this.

\section{Results and Discussion}

Cost and GWP of a plastic pot. This study determined the economic cost of producing a single petunia plant from initial propagation to retail delivery, using various alternative containers made from animal waste, plant materials, or bioplastics (Table 1). Koeser et al. (2014) produced a list of base-level inputs that contributed more than $0.5 \%$ of the $\mathrm{CO}_{2}$ emissions per petunia plant grown in a plastic container. We can consider the economic and social costs of each input together by comparing direct costs of production to GWP for producing the industry standard flat of 18 finished petunia plants (Table 2).

The results of the economic analysis of a plastic pot reveal that during the plug stage, most inputs contributed higher percentages to direct costs than to GWP. Therefore, the economic cost percentage exceeded the social cost percentage to the environment. The exception to this finding was that electricity consumption consisted of $46.7 \%$ of total GWP, but only $0.4 \%$ of the direct costs. These data only reflected the $\mathrm{kWh}$ price reported for lighting and irrigation and did not account for investment costs for lighting and irrigation systems. Such investment costs would have changed the result because our simulations included supplemental lighting, although this practice is not common in most operations. The lighting system consisted of $600-\mathrm{W}$, high-pressure sodium grow lamps covering an area of $10.5 \mathrm{~m}^{2}$ each. The lamps were operated so that they were on during early mornings and weekends $\left(24 \mathrm{~h} \cdot \mathrm{d}^{-1}\right)$ for a total run time of 73 $\mathrm{h} \cdot$ week $^{-1}$. Our results could also be different when electrical requirements for irrigation increase in the future when growers adopt alternative containers that have increased crop-watering requirements, such as bioplastic sleeve, coir, manure, peat, slotted rice, straw, and wood fiber (Koeser et al., 2013). The highest contributor to direct cost in the plug phase was labor. The plug phase contributed nearly half of the finished plant's cost and GWP (Table 2).

During the final stage of production, transportation, potting mix, fertilizer solution, and plastic shuttle tray, each contributed higher percentages to total GWP than to direct costs. The plastic container was the most costly input during the final stage and contributed a higher percentage to total direct costs than to total GWP. The overall highest contributors to GWP were electricity consumption, plastic shuttle tray, and plastic container. The overall highest contributors to direct cost were labor, plastic container, and paclobutrozol growth regulator (Table 2). The final stage of production reveals an opposite phenomenon compared with the plug stage. During the final stage, the economic costs of inputs contributed a lower percentage to total direct costs than to social costs and likely did not account for environmental concerns.

Variation by container type. We compared the costs of each input contributing more than $\$ 0.001$ per plant in the total direct COP when using different alternative container types (Table 3). Excluded costs under that threshold were municipal water, fertilizer, and paclobutrazol growth regulator applied during the plug stage. We also excluded the cost associated with the insecticide Paecilomyces fumosoroseus strain FE 9901, which we applied during the final stage because it was under the threshold. Before adding the price of the container, total direct production costs ranged from $\$ 0.56$ to $\$ 0.61$ per plant. The most influential factors affecting variation in cost before we added container prices were potting mix and paclobutrozol growth regulator. We saw little variation in the cost of municipal water (hundredths of a cent), although the alternative containers had slightly different volumes and abilities to retain moisture. However, this is highly dependent on the price of water, which varies greatly and will likely become more expensive in the future (OECD, 2012). Evans and Hensley (2004) found that a significant amount of water could be lost through container walls in certain types of biocontainers. Growers are encouraged to monitor water use in alternative containers and adjust irrigation rates for optimal plant growth. Although the cost of fertilizer solutions did not vary greatly among containers (reflecting only the amount of irrigation water applied), recent literature reports suggest that some biocontainers can release nitrogen as they break down, reducing the need for additional fertilizer (Schrader et al., 2013).

Different containers had different total direct costs of production ranging from $\$ 0.61$ to $\$ 0.97$ per plant after container costs were included. The least expensive containers were the recycled, reground pots, which Koeser et al. (2014) did not analyze, followed by bioplastic and the bioplastic sleeve. Wood fiber pots were the most expensive containers. Figure 1 shows the percent contribution of each biocontainer price to its total COP. Traditional 
plastic pots were neither most nor least expensive, contributing $18 \%$ to the COP compared with $41 \%$ for wood fiber and $6 \%$ for recycled, reground plastic.

The cost of labor using automated watering was the same among the container types but varied for production using hand watering (Fig. 2). For production using automated watering, the labor costs included seeding, moving trays, inspecting plants, transplanting, and loading for shipping. We added the time spent hand watering to the time spent performing these tasks. Hand watering added between $\$ 0.37$ and $\$ 0.54$ per plant in labor costs, depending on container type. Peat pots took the longest to water and bioplastic sleeves took the shortest amount of time to water (Fig. 2).

Figure 3 shows the total COP and GWP for each container, each calculated relative to the highest value for cost or GWP. Bioplastic pots have the potential to be an effective alternative to conventional plastic pots based on these results because of their lower cost and contribution to GWP, but they are no longer available from this manufacturer. They also had one of the lowest water demands of all containers as observed during previous research (Koeser et al., 2013), which could be important to growers faced with limited water supplies, strict regulations, or high water prices. Peat pots are the second-best alternative based on low cost and GWP, followed by coir pots (Fig. 3). Peat and coir pots are $\$ 0.009$ and $\$ 0.102$ more costly than conventional plastic pots, respectively, but contribute slightly less to GWP than plastic pots. However, the difference in GWP between plastic and biocontainer alternatives is not dramatic and does not represent a significant shift in sustainability. Koeser et al. (2014) reported that supplemental lighting during the plug stage accounted for $47 \%$ of total GWP compared with $16 \%$ for the plastic container. Therefore, the choice in container has limited impact on total GWP, and growers should perhaps base the choice of container on cost.

Table 1. Alternative containers compared with traditional plastic for carbon emissions and cost analysis.

\begin{tabular}{|c|c|c|c|}
\hline Container type & Product name ${ }^{z}$ & Volume $\left(\mathrm{cm}^{3}\right)$ & Manufacturer \\
\hline Bioplastic & TerraShellTM 10-cm H Wheat Pot & 473 & Summit Plastic Company \\
\hline Bioplastic sleeve & $11.4 \mathrm{~cm}$ Standard Assembled SoilWrapR & $709^{y}$ & Ball Horticultural Company, West Chicago, IL \\
\hline Coir & Coir $10.2 \mathrm{~cm}$ Std Fiber Gro Pot & 406 & Dillen Products, Middlefield, $\mathrm{OH}$ \\
\hline Manure & \#4 Square CowPot & 450 & CowPots Manufacturing and Sales \\
\hline Peat & $10.2 \mathrm{~cm}$ Jiffy Pot & $379^{y}$ & Jiffy Products of America Inc., Lorain, $\mathrm{OH}$ \\
\hline Plastic & Dillen 0.400 Standard Thinwall Green & 480 & $\begin{array}{l}\text { Myers Industries Lawn \& Garden Group, } \\
\text { Middlefield, OH }\end{array}$ \\
\hline Recycled, reground plastic & $10.2 \mathrm{~cm}$ plastic-12CMt-black plastic & 480 & Summit Plastic Company \\
\hline Slotted rice hull & $11.4 \mathrm{~cm} \mathrm{NetPot}$ & 591 & Summit Plastic Company \\
\hline Solid rice hull & Rice Pot $10.2 \mathrm{~cm}$ & 473 & Summit Plastic Company \\
\hline Straw & N/A & $646^{y}$ & Ivy Acres, Baiting Hollow, NY \\
\hline Wood fiber & $10 \times 10-\mathrm{cm}$ round individual Fertilpot & $430^{y}$ & Fertil SAS, Boulogne Billancourt, France \\
\hline
\end{tabular}

${ }^{\mathrm{z}}$ As indicated in manufacturer's online/print catalog.

${ }^{\mathrm{y}}$ Not included in manufacturer specifications. Volume measured by substrate displacement.

$\mathrm{N} / \mathrm{A}=$ not available.

Table 2. Base-level inputs and transportation requirements for plastic pots included in emission analysis and their corresponding direct cost per plant and 18-cell flat, and percent contribution to the flat's direct cost and global warming potential (GWP).

\begin{tabular}{|c|c|c|c|c|c|}
\hline & Input $^{z}$ & $\begin{array}{c}\text { Direct cost } \\
\text { per plant }(\$)\end{array}$ & $\begin{array}{l}\text { Direct cost per } \\
18 \text {-cell flat }(\$)\end{array}$ & $\begin{array}{l}\text { Contribution to } \\
\text { direct cost }(\%)^{y}\end{array}$ & $\begin{array}{l}\text { Contribution to } \\
\text { GWP }(\%)\end{array}$ \\
\hline \multirow[t]{13}{*}{ Plug Stage } & Electricity for irrigation & $<0.00$ & $<0.00$ & $<0.0$ & 46.7 \\
\hline & Electricity for lighting & $<0.00$ & 0.05 & 0.4 & \\
\hline & Waste wood heat & 0.01 & 0.13 & 1.1 & 0.6 \\
\hline & Growing mix & 0.01 & 0.10 & 0.8 & 0.4 \\
\hline & Plug tray & 0.02 & 0.43 & 3.5 & 1.7 \\
\hline & Seed & 0.01 & 0.16 & 1.3 & $\mathrm{~N} / \mathrm{A}$ \\
\hline & Pyroclostrobin + boscalid fungicide & $<0.00$ & 0.03 & 0.3 & N/A \\
\hline & Ethephon growth regulator & $<0.00$ & 0.02 & 0.1 & N/A \\
\hline & Paclobutrozol growth regulator & $<0.00$ & 0.01 & 0.1 & N/A \\
\hline & Fertilizer solution & $<0.00$ & $<0.00$ & $<0.0$ & N/A \\
\hline & City water & $<0.00$ & $<0.00$ & $<0.0$ & N/A \\
\hline & Labor & 0.23 & 4.20 & 34.5 & N/A \\
\hline & & 0.28 & 5.13 & 42.1 & 49.3 \\
\hline \multirow[t]{13}{*}{ Final stage } & Transportation-diesel truck & $<0.00$ & 0.02 & 0.2 & 3.1 \\
\hline & Horticultural peat & 0.04 & 0.79 & 6.5 & 7.7 \\
\hline & Expanded perlite & 0.01 & 0.14 & 1.1 & 2.2 \\
\hline & Fertilizer solution & $<0.00$ & 0.03 & 0.2 & 1.7 \\
\hline & Plastic container & 0.12 & 2.21 & 18.2 & 16.0 \\
\hline & Plastic shuttle tray & 0.04 & 0.77 & 6.3 & 20.0 \\
\hline & Imidacloprid insecticide & $<0.00$ & 0.01 & 0.1 & $\mathrm{~N} / \mathrm{A}$ \\
\hline & Paclobutrozol growth regulator & 0.07 & 1.31 & 10.7 & N/A \\
\hline & $\begin{array}{l}\text { Paecilomyces fumosoroseus strain } \\
\text { FE } 9901 \text { insecticide }\end{array}$ & $<0.00$ & $<0.00$ & $<0.0$ & N/A \\
\hline & $\begin{array}{l}\text { Etridiazole }+ \text { thiophanate-methyl } \\
\text { fungicide }\end{array}$ & 0.01 & 0.15 & 1.2 & N/A \\
\hline & Labor & 0.09 & 1.61 & 13.2 & N/A \\
\hline & Municipal water & $<0.00$ & 0.02 & 0.2 & N/A \\
\hline & & 0.68 & 12.19 & 100.0 & 100.0 \\
\hline
\end{tabular}

${ }^{\mathrm{z}}$ Only inputs contributing $0.5 \%$ or more toward the emissions for a given production stage are included for GWP calculations.

${ }^{\mathrm{y}}$ Direct costs account for $10 \%$ cull rate in plug stage and $2 \%$ cull rate in final stage.

Adapted from Koeser et al. (2014).

$\mathrm{N} / \mathrm{A}=$ not available 


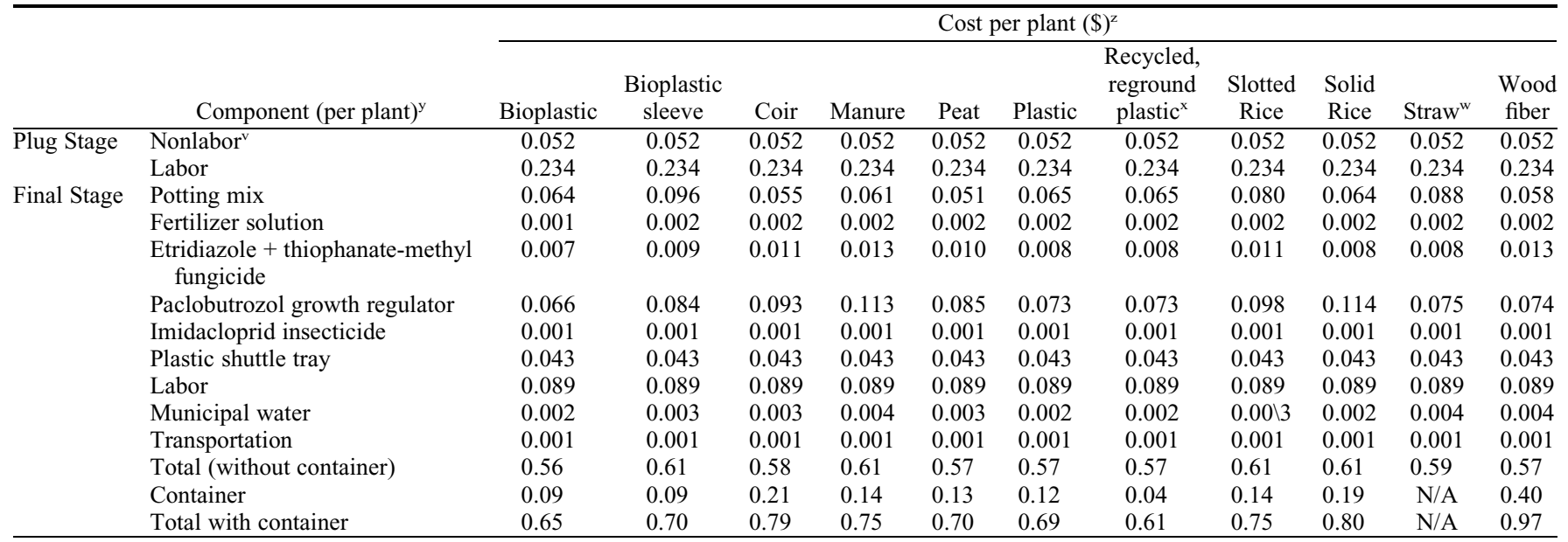

${ }^{\mathrm{z}}$ Only costs contributing $\$ 0.001$ or greater per plant were included.

${ }^{\mathrm{y}}$ Direct costs account for $10 \%$ cull rate in plug stage and $2 \%$ cull rate in final stage.

${ }^{\mathrm{x}}$ Recycled, reground plastic pots were not used in the study, so we used values from plastic pots for all components except container cost.

${ }^{\mathrm{w}} \mathrm{We}$ could not obtain the cost of straw containers.

${ }^{\mathrm{v}}$ Nonlabor cost inputs were the same for plug state inputs as follows per pot: seed $=\$ 0.009$, electricity $=\$ 0.003$, heat $=\$ 0.007$, growing mix $=\$ 0.006$, plug try $=$ $\$ 0.024$, pyroclostrobin + boscalid fungicide $=\$ 0.002$, ethephon growth regulator $=\$ 0.001$, paclobutrozol herbicide $=<\$ 0.000$.

$\mathrm{N} / \mathrm{A}=$ not applicable

Unfortunately, the most cost-effective container is a pot that Koeser et al. (2014) did not evaluate, one made from recycled and reground plastic. The reground plastic pots are a cheap alternative and currently available, and a candidate for further GWP research. We would expect plant growth and performance to be similar compared with plastic pots, but with a lower GWP. However, previous research indicates that this type of container may be unpopular with consumers, who favor biodegradable or compostable pots over recycled pots (Yue et al., 2011).

One consideration that Koeser et al. (2014) did not evaluate was the growth of plants in the different biocontainers. Koeser et al. (2013) found that under greenhouse conditions, dry shoot weight did vary by container type, with containers requiring the most water (i.e., irrigated when substrate moisture fell below $40 \%$ ) having the lowest shoot weights. However, other greenhouse and nursery studies have come to the opposite conclusion, finding similar plant growth among biocontainers as long as irrigation rate is sufficient (Evans and Hensley, 2004; Wang et al., 2015).

Our research looked at the impact of the container type on the economic and social costs of growing Petunia $\times$ hybrida in a large greenhouse production system. One could explore the impacts of other factors such as transportation costs and the world peat market on these economic and social costs. But our study was narrowly focused on the impact of container types on production costs and the environment.

\section{Conclusions}

Alternatives to plastic containers vary in $\mathrm{COP}$, in addition to their GWP. However, the

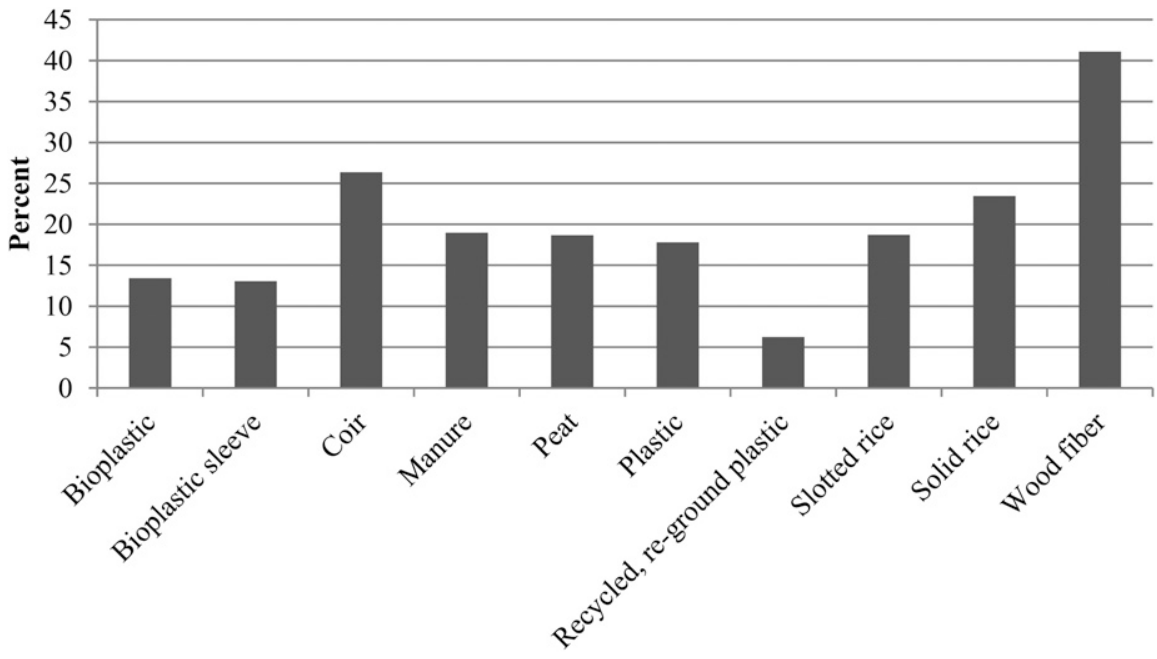

Fig. 1. Comparison of container price contribution to direct cost of a petunia plant grown in alternative containers. We could not obtain the cost of straw containers; therefore, straw containers we omitted from this figure.

difference in GWP was not as drastic as the difference in cost, with total direct costs ranging from $\$ 0.61$ to $\$ 0.97$ per pot. Although growers are concerned with sustainability and $\mathrm{CO}_{2}$ emissions, they will not likely adopt a product with low GWP if it is much more expensive. The relatively small differences in GWP among the different container types point to the fact that this is not a particularly distinguishing metric. Nevertheless, the environmental impact could be different, considering, for example, the slow breakdown of plastic in the environment. Given that the choice in container appears to have limited impact on total GWP (Fig. 3), growers should choose a type of container based on cost. Recycled, reground plastic pots have the lowest direct costs, and growers could reuse them to reduce their environmental impact. However, the return-and-cleaning process is cumbersome and labor-intensive. Similar to bottles and cans, some states have a plastic refund process that they could also consider for plastic pots. Because lighting is the largest contributor to GWP, growers may want to explore more energy-efficient lighting systems, for example LED lighting. However, the acquisition costs of such systems can be high. This may change as lighting manufacturers develop new systems for greenhouse production.

The actual cost of the coir pot most closely matched its social cost, possibly making it the most sustainable container examined in this study, assuming that plants grown in coir pots are of similar quality to 


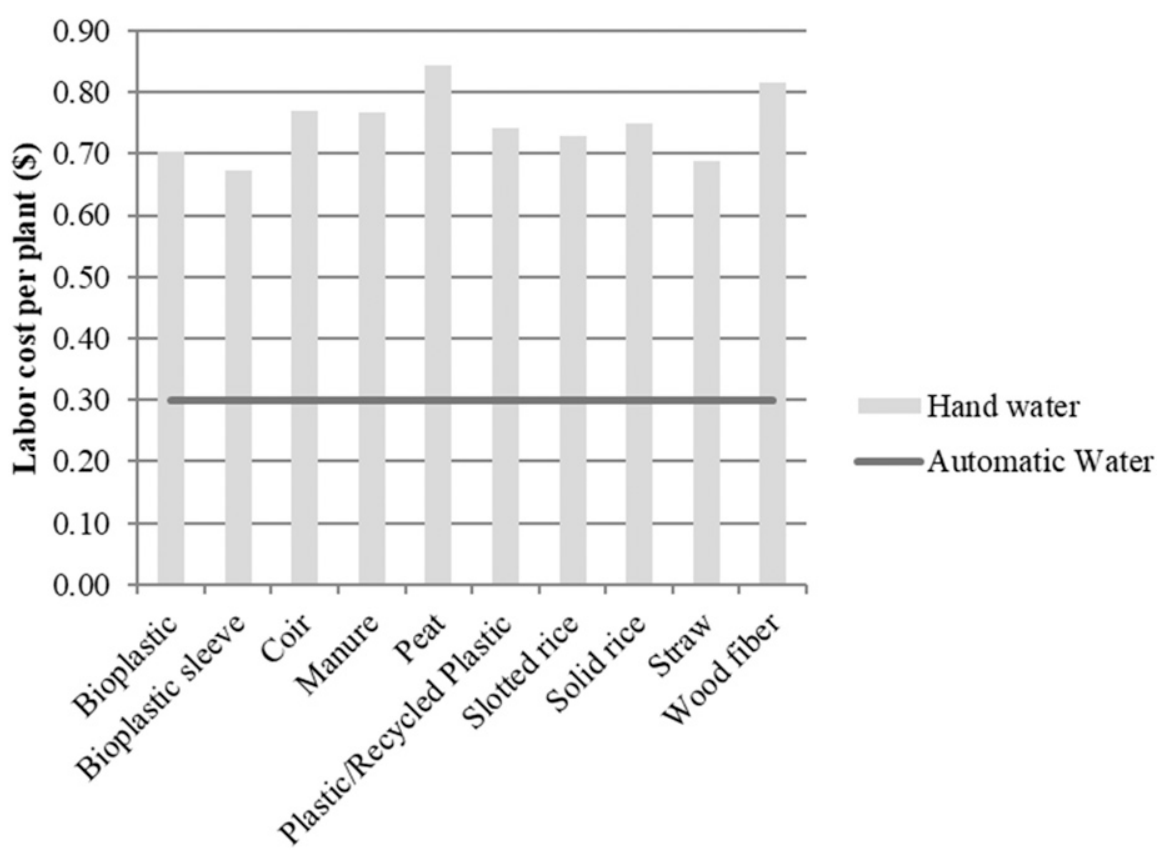

Fig. 2. Labor costs per plant associated with growing petunias in alternative containers using either automated watering or hand watering.

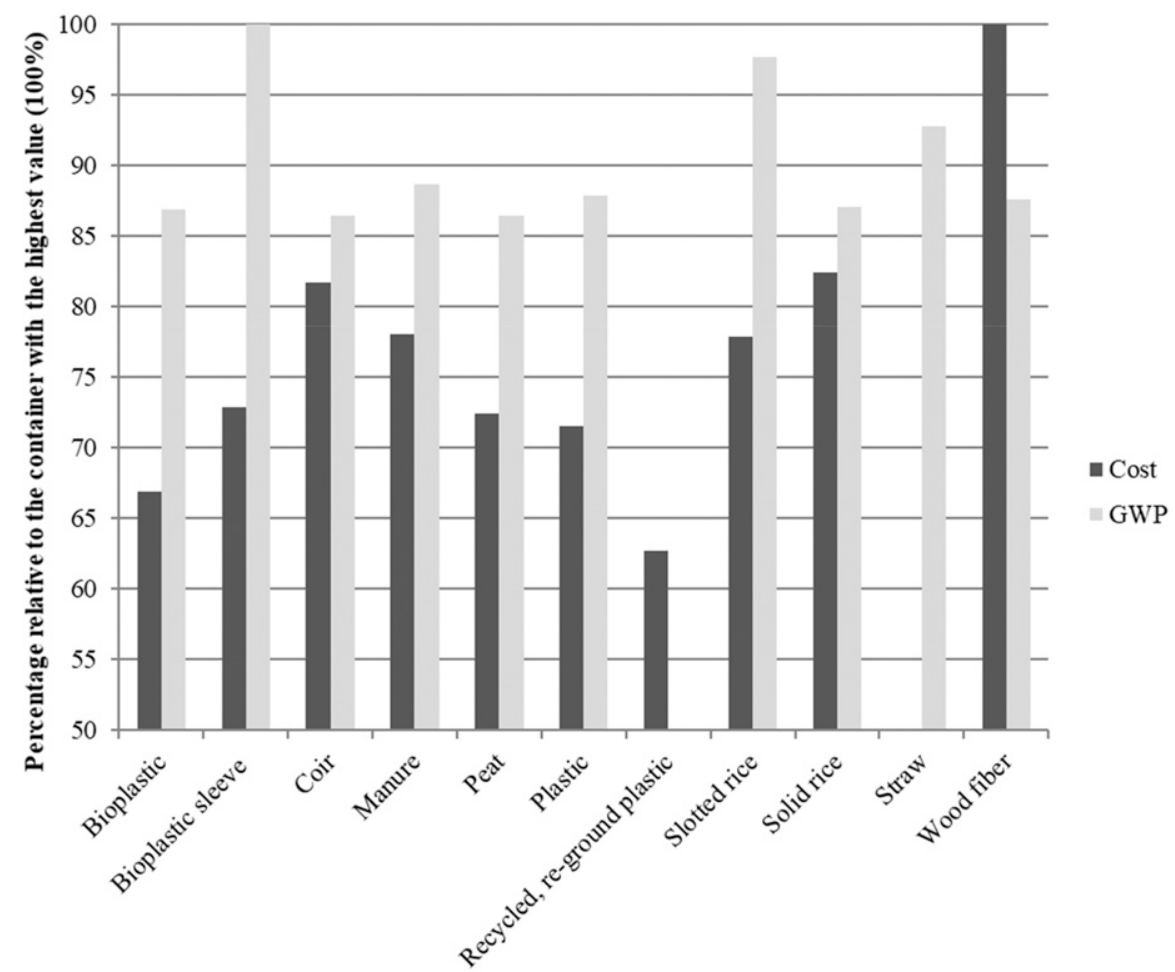

Fig. 3. Comparison of direct cost and global warming potential (GWP) (calculated as percent of highest value) of petunias grown in alternative containers. We could not obtain the cost of straw containers. Global warming potential calculation did not use recycled, reground plastic containers. Adapted from Koeser et al. (2014)

those grown in plastic pots. Most inputs for petunia production did not evenly contribute to the economic and social costs associated with overall production (Table 2 ). This highlights a disconnect between the economic price of inputs and their social costs. As long as society does not adequately capture environmental impact costs, it is unlikely that plant production characteristics. HortScience 48:200-208.

Brumfield, R.G., A.J. DeVincentis, X. Wang, R.T. Fernandez, S. Nambuthiri, R.L. Geneve, A.K. Koeser, G. Bi, T. Li, Y. Sun, G. Niu, D Cochran, A. Fulcher, and J.R. Stewart. 2015. Economics of utilizing alternative containers in ornamental crop production systems. HortTechnology 25:17-25.

Circle of Blue. n.d. The price of water. 15 Feb. 2018. <http://www.circleofblue.org/waterpricing >

Dennis, J.H., R.G. Lopez, B.K. Behe, C.R. Hall, C Yue, and B.L. Campbell. 2010. Sustainable production practices adopted by greenhouse and nursery plant growers. HortScience 45:1232-1237.

Evans, M.R. and D.L. Hensley. 2004. Plant growth in plastic, peat, and processed poultry feather fiber growing containers. HortScience 39:10121014.

Hall, C.R., B.J. Campbell, B.K. Behe, C. Yue, R.G. Lopez, and J.H. Dennis. 2010. The appeal of biodegradable packaging to floral consumers. HortScience 45:583-591.

Hall, C.R. and D. Ingram. 2014. Production costs of field-grown Cercis canadensis L. 'forest pansy' identified during life cycle assessment analysis. HortScience 29:622-627.

Hall, T.J., J.H. Dennis, R.G. Lopez, and M.I. Marshall. 2009. Factors affecting growers' willingness to adopt sustainable floriculture practices. HortScience 44:1346-1351.

Hodges, A.W., H. Khachatryan, M.A. Palma, and C.R. Hall. 2015. Production and marketing practices and trade flows in the United States green industry in 2013. J. Environ. Hort. 33: 125-136.

Koeser, A., S.T. Lovell, M. Evans, and J.R. Stewart. 2013. Biocontainer water use in short-term greenhouse crop production. HortTechnology 23:215-219.

Koeser, A., S.T. Lovell, A.C. Petri, R.G. Brumfield, and J.R. Stewart. 2014. Biocontainer use in a Petunia $\times$ hybrida greenhouse production system: A cradle-to-gate carbon footprint assessment of secondary impacts. HortScience 49:265-271

Laroche, M., J. Bergeron, and G. Barbaro-Forleo. 2001. Targeting consumers who are willing to pay more for environmentally friendly products. J. Consum. Mark. 18:503-520.

Lubick, N. 2007. Plastics in from the bread basket. Environ. Sci. Technol. 1:6639-6640.

Moore, F.C., U. Baldos, T. Hertel, and D. Diaz. 2017. New science of climate change impacts on agriculture implies higher social cost of carbon. Nature Communications. 8:1607. 20 Feb. 2018. <https://www.nature.com/articles/ s41467-017-01792-x>.

Nordhaus, W.D. 2017. Revisiting the social cost of carbon. Proceedings of the National Academy of Sciences of the USA. 20 Feb. 2018. <https:// www.nature.com/articles/s41467-017-01792-x>.

OECD. 2012. Agriculture and water quality: Monetary costs and benefits across OECD Countries. 20 Feb. 2018. <https://www.oecd.org/tad/ sustainable-agriculture/49841343.pdf>

Russo, M.V. and P.A. Fouts. 1997. A resource-based perspective on corporate environmental performance and profitability. Acad. Mgt. J. 40:534-559.

Schrader, J.A., H. Kratcsh, and W.R. Graves. 2016. Bioplastic container cropping systems, green technology for the green industry. Sustainable Hort. Res. Consortium, Ames, IA.

Schrader, J.A., G. Srinivasan, D. Grewell, K.G McCabe, and W.R. Graves. 2013. Fertilizer effects of soy-plastic containers during crop 
production and transplant establishment. HortScience 48:724-731.

Sun, Y., G. Niu, A.K. Koeser, G. Bi, V. Anderson, K. Jacobsen, R. Conneway, S. Verlinden, R. Stewart, and S.T. Lovell. 2014. Impact of biocontainers on plant performance and container decomposition in the landscape. HortTechnology 25:63-70.

USDA National Agricultural Statistics Service. 2016. Floriculture crops 2015 summary.

U.S. Energy Information Administration. 2017. Average retail price of electricity to ultimate customers. 23 Jan. 2018. <https://www.eia. gov/electricity/data.php\#sales>.

U.S. Environmental Protection Agency. 2012. TRACI 2 - Tool for the reduction and assessment of chemical and other environmental impacts. 8 May 2018. <https://www.epa.gov/chemicalresearch/tool-reduction-and-assessment-chemicalsand-other-environmental-impacts-traci>.

Vandenbussche, M., P. Chambrier, S. Rodrigues Bento, and P. Morel. 2016. Petunia, your next supermodel? Front. Plant Sci., doi: 10.3389/ fpls.2016.00072.
Wang, X., R.T. Fernandez, B.M. Cregg, R. Auras, A. Fulcher, D.R. Cochran, G. Niu, Y. Sun, G. Bi, S. Nambuthiri, and R.L. Geneve. 2015. Multistate evaluation of plant growth and water use in plastic and alternative nursery containers. HortTechnology 25:4249.

Yue, C., J.H. Dennis, B.K. Behe, C.R. Hall, B.L. Campbell, and R.G. Lopez. 2011. Investigating consumer preference for organic, local, or sustainable plants. HortScience 46:610-615. 